\title{
Assessing Sustainability Indicators of a Commercial Building: A LEED Approach
}

\author{
Mohamed Abdelmawjoud Abdelgaffar \\ College of Architecture \& Planning, \\ University of Dammam, Saudi Arabia
}

(Received:18 / 02/ 2010, Accepted: 09/04/2011)

\begin{abstract}
Construction industry has been proven to cause environmental problems ranging from excessive consumption of natural resources in construction, to the pollution of the environment. Studies on green building to minimize environmental impact are already underway. Tools of assessment of environmental performance of buildings are plenty. However, Middle East countries together with Gulf region are still away from practicing the concept of mitigating the impacts of buildings on the environment. Reasons could be relying on the insufficient awareness of building stakeholders, or the privilege of much fortune. The main objectives of this paper are to arouse the people's attention to the importance of assessment of environmental performance of buildings in KSA, and to introduce a sustainability model for project appraisal based on a multi-dimensional approach, that will be used for the assessment of a case study in KSA. The approach is using the LEED (Leadership in Energy and Environmental Design) rating system as a guide for the assessment. The plan of work includes reviewing the literature on the assessment of sustainability performance of buildings, displaying the LEED system, and assessment of a commercial building in Dammam. The paper uses the descriptive approach to study the problem and collect the data, and the comparative approach to compare the obtained data with the required standards of LEED. The case study, which is a commercial complex in Dammam, is one of these types of buildings widely spread in the development schemes of current real estate investment in KSA. While the building achieved some credits and prerequisites of LEED system, the building lacks many other points. The overall credits achieved are $22 \%$, and the overall prerequisites achieved are $43 \%$. The main problem of the building is related to energy and atmosphere aspects. The maximum performance efficiency
\end{abstract}


of the building is recorded in water use, which is relatively accepted. As a result, the building is poor in its environmental performance. The building needs much more thorough studies and environmental management policies to enhance its sustainability criteria for better microclimate, health, and productivity for the occupants and users, and for a better environmental quality for the site location and surrounding context.

Keywords: Building performance; Environmental assessment; Sustainable construction; Sustainable development, LEED.

\section{Introduction}

There are concerns about how to improve construction practices to minimize their effects on the natural environment. The environmental impact of construction, green buildings, designing for recycling and ecolabeling of building materials, have captured the attention of building professionals across the world. Building performance is a major concern in the building industry and environmental building performance assessment has emerged as one of the major issues in sustainable construction ${ }^{[1]}$. The built environment has a profound impact on our natural environment, economy, health, and productivity. Buildings affect people's lives and the health of the planet and transform land that provides valuable ecological resources (Fig. 1). In the United States alone, buildings account for: $72 \%$ of electricity consumption, $39 \%$ of energy use, $38 \%$ of all carbon dioxide emissions, $40 \%$ of raw materials use, $30 \%$ of waste output, and $14 \%$ of potable water consumption ${ }^{[2]}$.

The research importance is reflected in promoting the green concept in building industry in order to gain the potential vital advantages of the green building and to eliminate the serious problems of traditional building techniques. This helps create a more sustainable community for current and future generations.

The way of life in the Gulf countries is very far from sustainable criteria and performance. High consumption rates, resource exhaustion, dispersed communities, gated development accompanied with low densities and very luxurious schemes, very excessive car use, huge energy consumption of air-conditioning and transportation, excessive water usage, waste and pollution, etc. all constitute crucial problems that threaten the future of life in and out of the gulf countries. Unsustainable construction industry forms serious problems with the excessive 
expansion and the huge increase in construction industry and real estate development. Researcher should emphasize on decreasing the environmental problems related to construction industry, a small effort enhancing the performance of construction, will have great revenues with the huge capital investment in real estate industry in the Gulf countries.

The aims of work are: 1) to protect the environment and natural resources, 2) to identify the principles of sustainable construction, 3) and to assess the performance of a commercial building based on the LEED system.

The plan of work includes reviewing the literature on the assessment of sustainability performance of buildings, displaying the LEED system, assessment of a commercial building in Dammam, KSA. The data presented here are collected based on observation of the current situation and performance of the building, together with interviews with the design office working and interacting with the building.

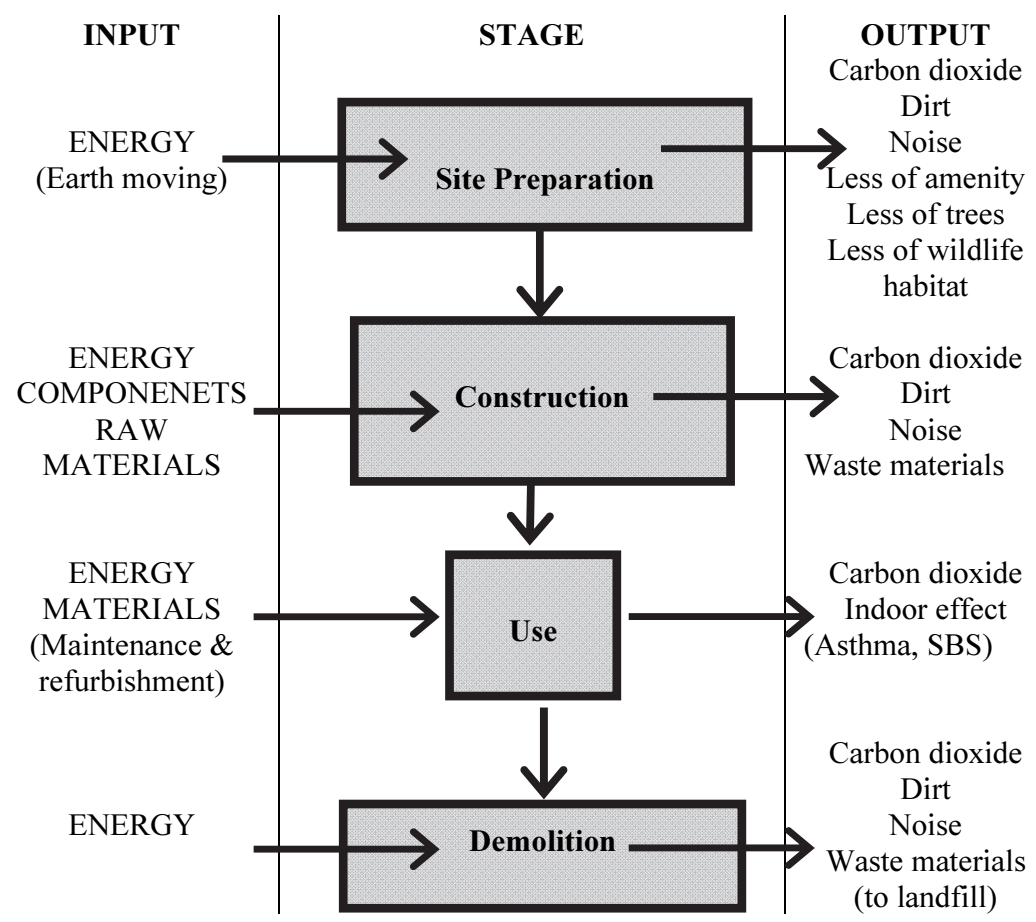

Fig. 1. Environmental impact of buildings through its life-cycle ${ }^{[3]}$. 


\section{Indicators and Instruments}

Building sector started to realize the impact of their activities on the environment in the 1990s. Environmental indicators were developed for the needs of interest groups. The first attempt to establish means of assessing environmental impacts in buildings was the Building Research Establishment Environmental Assessment Method (BREEAM). It was in 1990 in the $\mathrm{UK}^{[4]}$. Since then, many tools have been launched around the world such as LEED, BEES, Green Building Tool, and HK-BEAM. Based on the previous studies, the indicators for measuring a construction's environmental performance include general environmental impact, utilization of environmental resources, contribution to sustainability, public impact, and care for labor ${ }^{[5]}$. Table 1 indicates the factors affecting the environmental impacts of buildings. There are many tools to environmentally improve buildings. Some of these approaches have mandatory requirements. Others are of a guidance type to show potential for improvement.

Table 1. Factors influencing environmental impact associated with buildings.

\begin{tabular}{|c|c|c|c|c|}
\hline 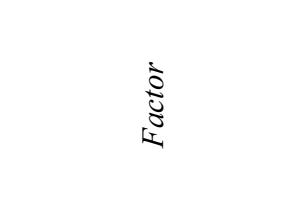 & 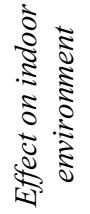 & 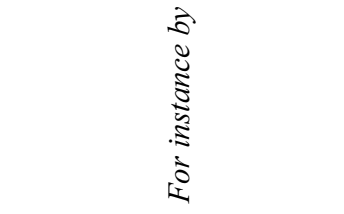 & 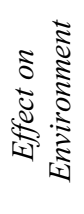 & $\begin{array}{l}\text { పे } \\
0 \\
\vdots \\
\vdots \\
\vdots \\
\vdots \\
\vdots \\
\vdots \\
0\end{array}$ \\
\hline Design & Yes & Ventilation & Yes & Influencing energy use \\
\hline Sitting/orientation & Yes & $\begin{array}{c}\text { Radon exhalation soil and } \\
\text { influence on energy use } \\
\text { and } \\
\text { Indoor temperature } \\
\end{array}$ & Yes & Effect on landscape \\
\hline $\begin{array}{l}\text { Location and } \\
\text { infrastructure }\end{array}$ & Yes & $\begin{array}{l}\text { Determining quality } \\
\text { incoming Air }\end{array}$ & Yes & $\begin{array}{l}\text { Influencing transport } \\
\text { from and to building }\end{array}$ \\
\hline $\begin{array}{l}\text { Building materials } \\
\text { construction/maintena } \\
\text { nce/ refurbishment }\end{array}$ & Yes & Exhalation of volatiles & Yes & $\begin{array}{l}\text { Life cycle impacts } \\
\text { with various effects }\end{array}$ \\
\hline User behavior & Yes & Smoking & Yes & $\begin{array}{l}\text { Influencing water and } \\
\text { energy use }\end{array}$ \\
\hline $\begin{array}{l}\text { Energy input during } \\
\text { use }\end{array}$ & Yes & Combustion products & Yes & $\begin{array}{l}\text { Life cycle impacts of } \\
\text { energy supply }\end{array}$ \\
\hline $\begin{array}{l}\text { Water input during } \\
\text { use }\end{array}$ & No & & Yes & $\begin{array}{l}\text { Life cycle impacts of } \\
\text { water supply }\end{array}$ \\
\hline Demolition & No & & Yes & Solid wastes \\
\hline
\end{tabular}

Source: Reijnders, L., and Roekel, A. van, Comprehensiveness and adequacy of tools for the environmental improvement of buildings, Journal of Cleaner Production, 7, 221-225, (1999). 


\subsection{Requirement Type Instruments}

An environmentally mandatory requirements in Europe is summarized in Table 2. At the building level, requirements relate to energy and water consumption efficiency, and to demolition and the wastes generated. There are very limited mandatory requirements related to building components and materials used in buildings. The mandatory requirements have limited interactions between buildings and the environment. It seems that mandatory requirements are not a source for comprehensive improvements ${ }^{[5]}$.

Table 2. Mandatory requirements in European countries.

\begin{tabular}{lllllllll}
\hline & & & & \\
\hline
\end{tabular}

Source: Reijnders, L., and Roekel, A. van, Comprehensiveness and adequacy of tools for the environmental improvement of buildings, Journal of Cleaner Production, 7, 221-225, (1999).

\subsection{Guidance Type Instruments}

In European and North American countries, there are many of relatively comprehensive instruments that include ${ }^{[5]}$ :

- Environmental preference lists for building materials and components;

- Manuals for sustainable building; 
○ Eco-labeling schemes for building products;

○ Life cycle analysis for the environmental improvement of building;

○ Scoring systems, suggesting environmental improvements;

- Blueprints to set the standard for an environmentally improved building;

- Computer-based guidance for the improvements of complete buildings.

The approaches including products comparisons and information sources are BEES 4 (Building for Economic and Environmental Sustainability), and TEAM ${ }^{[4]}$. BEES implements a rational systematic technique for selecting environmentally preferred, cost -effective building products. It is a Window based software includes actual economic and environmental performance data for over 230 building products ${ }^{[6]}$. The approaches including full LCA of buildings are ECOPTECOPRO-ECOREAL, ECO-QUANTUM, and ATHENA. These instruments allow for quantitative environmental assessment of differences in building design, component and materials choice. Table 3 shows some of these methods and their coverage of the indoor environment and environmental impacts in general. While Table 4 displays the list of building assessment tools, origin, and characteristics.

The scoring methods include:

- LEED (Leadership in Energy and Environmental Design), USA

- BEPAC (Building Environmental Performance Assessment Criteria), Canada

○ Eco-Profile for buildings, Norway

- BREEAM, the United Kingdom

All instruments consist of lists of suggestions for the improvement of buildings linked with a score. Therefore the paper emphasizes on one of the tools that have recently been developed and widely spread in assessment of building performance, LEED, which covers almost all the factors influencing environmental impacts associated with buildings except user behavior (Fig. 2). 
Table 3. Coverage of factors influencing environmental impacts associated with buildings.

\begin{tabular}{|c|c|c|c|c|c|c|c|c|c|}
\hline$\frac{\sqrt{2}}{\frac{2}{2}}$ & 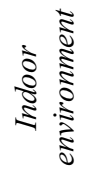 & $\begin{array}{l}50 \\
50 \\
0\end{array}$ & $\stackrel{\omega_{0}^{2}}{\stackrel{\Sigma}{\Sigma}}$ & 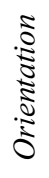 & 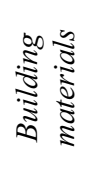 & $\frac{\vdots}{\grave{d}}$ & 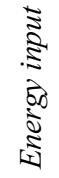 & 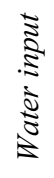 & 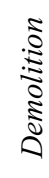 \\
\hline ATHENA & 0 & +++ & 0 & 0 & +++ & 0 & 0 & 0 & + \\
\hline BREEAM & + & ++ & + & + & + & + & ++ & + & 0 \\
\hline EcoProfile & ++ & ++ & + & + & + & + & ++ & + & + \\
\hline $\begin{array}{l}\text { ECOPT- } \\
\text { ECOPRO/E } \\
\text { COREAL }\end{array}$ & 0 & +++ & 0 & + & +++ & 0 & ++ & 0 & ++ \\
\hline $\begin{array}{l}\text { ECO- } \\
\text { QUANTUM }\end{array}$ & 0 & +++ & 0 & + & +++ & 0 & ++ & + & ++ \\
\hline
\end{tabular}

0: No (direct coverage); +: Limited (direct) coverage; ++: Substantial coverage; +++: Extensive coverage.

Source: Reijnders, L., and Roekel, A. van, Comprehensiveness and adequacy of tools for the environmental improvement of buildings, Journal of Cleaner Production, 7, 221-225, (1999).

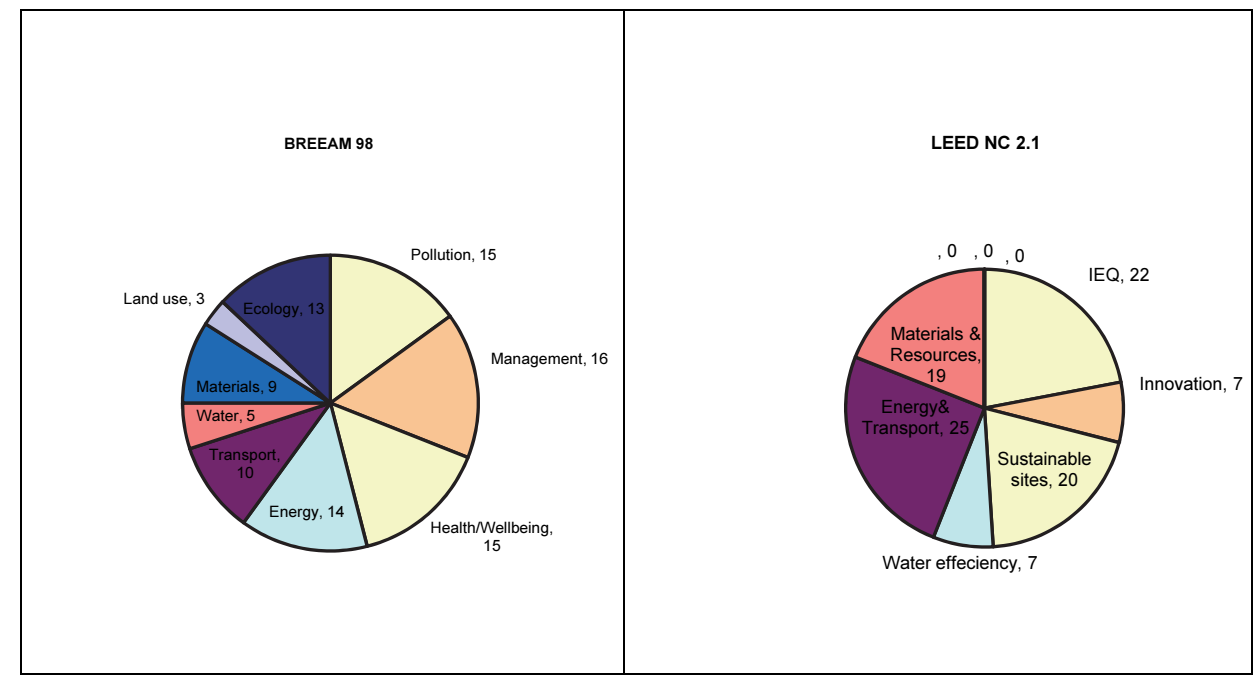

Fig. 2. BREEAM and LEED components ${ }^{[7]}$.

\section{Benefits of Green Building}

A clear definition for a green building is provided by ASTM (2001) "a building that provides the specified building performance requirements while minimizing disturbance to and improving the functioning of local, regional, and global ecosystems both during and after its construction and specified service life, a green building 
optimizes efficiencies in resource management and operational performance; and minimizes risks to human health and the environment" ${ }^{\prime[8]}$. The notion includes improved eco-efficiency, economic and social dimensions of sustainable development ${ }^{[7]}$.

Green buildings have many advantages over the traditional ones ${ }^{[2]}$.

- Environmental benefits: Enhance and protect ecosystems and biodiversity, improve air and water quality, reduce solid waste, conserve natural resources;

- Economic benefits:Reduce operating costs, enhance asset value and profits, improve employee productivity and satisfaction, optimize life-cycle economic performance;

- Health and community benefits: Improve air, thermal and acoustic environments, enhance occupant comfort and health, minimize strain on local infrastructure, and contribute to overall quality of life.

Table 4. Summary of environmental building performance assessment methods.

\begin{tabular}{|c|c|c|c|}
\hline \multicolumn{2}{|c|}{ Assessment methods } & \multirow{2}{*}{$\begin{array}{l}\text { Origin } \\
\begin{array}{l}\text { Department } \\
\text { of } \\
\text { Commence, } \\
\text { NSW, 2005 }\end{array}\end{array}$} & \multirow{2}{*}{$\begin{array}{l}\text { Characteristics } \\
\text { A performance-based accredited assessment tool } \\
\text { Using star rating on a scale of one to five star } \\
\text { Provide a national approach to benchmarking } \\
\text { greenhouse performance of buildings and tenancies } \\
\text { Based on } 12 \text { months of energy consumption }\end{array}$} \\
\hline ABGR & $\begin{array}{l}\text { Australian } \\
\text { Building } \\
\text { Greenhouse } \\
\text { Rating }\end{array}$ & & \\
\hline AccuRate & & $\begin{array}{l}\text { CSIRO, } \\
2006\end{array}$ & $\begin{array}{l}\text { The new version of NatHERs } \\
\text { Addresses problems associated with rating homes in } \\
\text { tropical and sub-tropical environment through the } \\
\text { inclusion of a ventilation model } \\
\text { It includes an extensive database of materials } \\
\text { Allows users to modify construction elements }\end{array}$ \\
\hline BASIX & $\begin{array}{l}\text { Building } \\
\text { sustainability } \\
\text { Index }\end{array}$ & $\begin{array}{l}\text { Department } \\
\text { of } \\
\text { Infrastructur } \\
\text { e, Planning } \\
\text { and Natural } \\
\text { Resources, } \\
2004\end{array}$ & $\begin{array}{l}\text { Web-based planning tool for residential development } \\
\text { To assess the water and energy efficiency of new } \\
\text { residential developments } \\
\text { NatHERS and AccuRate are simulation packages } \\
\text { used to assess energy performance } \\
\text { It is mandatory for all new residential development } \\
\text { and a BASIX certificate is required for development } \\
\text { approval }\end{array}$ \\
\hline BEPAC & $\begin{array}{l}\text { Building } \\
\text { environmental } \\
\text { performance } \\
\text { assessment } \\
\text { criteria }\end{array}$ & $\begin{array}{l}\text { Canada, } \\
1993\end{array}$ & $\begin{array}{l}\text { Developed by the University of British Columbia } \\
\text { Similar to BREEAM but a more detailed and } \\
\text { comprehensive assessment method } \\
\text { Limited to new and existing office } \\
\text { Uses a point system for rating, A voluntary tool }\end{array}$ \\
\hline
\end{tabular}




\begin{tabular}{|c|c|c|c|}
\hline CASBEE & $\begin{array}{l}\text { Comprehensive } \\
\text { assessment } \\
\text { system for } \\
\text { building } \\
\text { environmental } \\
\text { efficiency }\end{array}$ & Japan, 2004 & $\begin{array}{l}\text { A co-operative project between industry and } \\
\text { government } \\
\text { Applicable in accordance with the stages of a } \\
\text { development in pre-design, new construction, } \\
\text { existing building and renovation } \\
\text { It is based on the concept of closed ecosystems to } \\
\text { determine the environmental capacities } \\
\text { Consideration for regional character }\end{array}$ \\
\hline CEPAS & $\begin{array}{l}\text { Comprehensive } \\
\text { environmental } \\
\text { performance } \\
\text { assessment } \\
\text { scheme }\end{array}$ & HK, 2001 & $\begin{array}{l}\text { Developed by the Building Department } \\
\text { For all types of existing and new buildings } \\
\text { To serve as a unified yardstick for a common, } \\
\text { comprehensive assessment scheme for buildings } \\
\text { Eight performance categories } \\
\text { Employing an additive/weighting approach }\end{array}$ \\
\hline CPA & $\begin{array}{l}\text { Comprehensive } \\
\text { project } \\
\text { Evaluation }\end{array}$ & UK, 2001 & $\begin{array}{l}\text { Developed by the Royal Institution of Chartered } \\
\text { Surveyors and the Environment Agency } \\
\text { Different from a building performance method as it } \\
\text { is used to assess projects during the development } \\
\text { process using a combination of financial \& economic } \\
\text { approach } \\
\text { A multi-criteria analysis approach to assess } \\
\text { environmental and social impacts of a project } \\
\text { A checklist-type evaluation framework that requires } \\
\text { an independent assessor to undertake the assessment } \\
\text { A voluntary tool }\end{array}$ \\
\hline SPeAR & $\begin{array}{l}\text { Sustainable } \\
\text { project } \\
\text { appraisal } \\
\text { routine }\end{array}$ & & $\begin{array}{l}\text { A project assessment methodology within Over } \\
\text { Arup's consulting projects } \\
\text { To enable a rapid review of project sustainability } \\
\text { Use a graphical format to present sustainable design } \\
\text { To identify opportunities to optimize performance } \\
\text { Rated on a scale of }+3 \text { to }-3 \\
\text { In } 4 \text { main elements: environment, social, economic } \\
\text { and natural resources }\end{array}$ \\
\hline $\begin{array}{l}\text { Eco- } \\
\text { Quantum }\end{array}$ & & Netherlands & $\begin{array}{l}\text { The only method that is explicitly and } \\
\text { comprehensively based on life-cycle assessment } \\
\text { Assess the environmental burden of a complete } \\
\text { building on the basis of LCA } \\
\text { Easy to use and has extensive database of the most } \\
\text { commonly used materials and products } \\
\text { Not a comprehensive assessment method } \\
\text { Only applicable to single residential buildings }\end{array}$ \\
\hline EMGB & $\begin{array}{l}\text { Evaluation } \\
\text { manual for } \\
\text { green buildings }\end{array}$ & $\begin{array}{l}\text { Taiwan, } \\
1998\end{array}$ & $\begin{array}{l}\text { Operated by the Ministry of Interior } \\
\text { Consists of } 9 \text { environmental criteria } \\
\text { A single tool for all types of buildings } \\
\text { Not able to reflect regional differences } \\
\text { Only assess the quantifiable criteria and non } \\
\text { quantifiable issues are omitted } \\
\text { Assess the least number of performance criteria }\end{array}$ \\
\hline
\end{tabular}




\begin{tabular}{|c|c|c|c|}
\hline EPGB & $\begin{array}{l}\text { Environmental } \\
\text { performance } \\
\text { guide for } \\
\text { building }\end{array}$ & $\begin{array}{l}\text { Department } \\
\text { of Public } \\
\text { Works and } \\
\text { Services, } \\
\text { NSW }\end{array}$ & $\begin{array}{l}\text { Assess buildings using a framework of } \\
\text { environmental performance into } 5 \text { categories } \\
\text { Useful to consider resource consumption \& loadings } \\
\text { Buildings are rated and a single indicator for the total } \\
\text { performance }\end{array}$ \\
\hline DQI & $\begin{array}{l}\text { Design quality } \\
\text { indicator }\end{array}$ & UK & $\begin{array}{l}\text { Supported by the UK Construction Industry Council } \\
\text { A toolkit used throughout the development process } \\
\text { Aims at improving the design of buildings by } \\
\text { providing feedback and capturing perceptions of } \\
\text { design quality embodied in buildings } \\
\text { Assess buildings in three main categories: } \\
\text { functionality, build quality and impact } \\
\text { Aim at assisting clients in defining their aspirations to } \\
\text { which project's success will be measured against }\end{array}$ \\
\hline GBTool & $\begin{array}{l}\text { Green building } \\
\text { challenge }\end{array}$ & $\begin{array}{l}\text { Internationa } \\
11995\end{array}$ & $\begin{array}{l}\text { The most comprehensive framework } \\
\text { International collaboration of over } 20 \text { countries } \\
\text { Absolute performance indicators to complement the } \\
\text { relative scores } \\
\text { More than } 90 \text { individual performance assessment } \\
\text { Four levels of weighting }\end{array}$ \\
\hline GHEM & $\begin{array}{l}\text { Green home } \\
\text { evaluation } \\
\text { Manual }\end{array}$ & China, 2001 & $\begin{array}{l}\text { Introduced by the Science and Technology } \\
\text { Development Promoting Centre and Ministry of } \\
\text { Construction } \\
\text { The first environmental standards and design } \\
\text { guidelines related to performance standards } \\
\text { Only relates to residential projects } \\
\text { Simple rating that without explicit weighting system } \\
\text { to address resources allocation and indoor } \\
\text { environmental quality } \\
\text { No clear definition for the degree of severity for } \\
\text { unsatisfied pre-requisite requirements }\end{array}$ \\
\hline $\begin{array}{l}\text { Green } \\
\text { Star }\end{array}$ & & $\begin{array}{l}\text { Green } \\
\text { Building } \\
\text { Council }\end{array}$ & $\begin{array}{l}\text { Australia's first comprehensive method for } \\
\text { evaluating environmental building performance } \\
\text { For commercial buildings only } \\
\text { Rating system on a scale from } 0 \text { to } 6 \text { stars }\end{array}$ \\
\hline $\begin{array}{l}\text { HKBEA } \\
\text { M }\end{array}$ & $\begin{array}{l}\text { Hong Kong } \\
\text { building } \\
\text { environmental } \\
\text { assessment } \\
\text { method }\end{array}$ & $\begin{array}{l}\text { Hong Kong, } \\
1996\end{array}$ & $\begin{array}{l}\text { Has separate assessment methods for new and } \\
\text { existing office buildings } \\
\text { It has been criticized as assessing the quantifiable } \\
\text { criteria but the non-quantifiable social and } \\
\text { environmental issues have been deliberately ignored } \\
\text { Assessing new building 'as built' rather than 'as } \\
\text { designed' } \\
\text { Assessment process not transparent } \\
\text { Assessment categorized under the global, local \& } \\
\text { indoor scales } \\
\text { Emphasis on life-cycle impacts } \\
\text { Assessing building performance in grades ranging } \\
\text { from fair to excellent }\end{array}$ \\
\hline
\end{tabular}




\begin{tabular}{|c|c|c|c|}
\hline LEED & $\begin{array}{l}\text { Leadership in } \\
\text { energy and } \\
\text { environmental } \\
\text { design }\end{array}$ & USA, 2000 & $\begin{array}{l}\text { Developed by the US Green Building Council } \\
\text { A certification process developed to create an } \\
\text { industrial standard } \\
\text { Self-assessing system awards rating of certified, } \\
\text { silver, gold and platinum } \\
\text { Use simple checklist format to rate building } \\
\text { performance } \\
\text { For new and existing commercial, institutional, high- } \\
\text { rise residential \& major renovation } \\
\text { Comprises } 5 \text { areas of sustainability } \\
\text { A voluntary tool }\end{array}$ \\
\hline NABERS & $\begin{array}{l}\text { National } \\
\text { Australian } \\
\text { building } \\
\text { environmental } \\
\text { rating system }\end{array}$ & $\begin{array}{l}\text { Department } \\
\text { of } \\
\text { Environmen } \\
t \text { and } \\
\text { Heritage, }\end{array}$ & $\begin{array}{l}\text { A performance-based rating system that measures an } \\
\text { existing building's overall environmental } \\
\text { performance during operation } \\
\text { For existing commercial buildings and houses } \\
\text { Self-assessment accredited ratings score out of } 10\end{array}$ \\
\hline NatHERS & & CSIRO & $\begin{array}{l}\text { Computer-based house energy rating system } \\
\text { To give houses an energy efficiency rating from } 0 \text { to } \\
5 \text { stars } 0 \text { star being inefficient whilst } 5 \text { star indicates } \\
\text { high level of energy efficiency }\end{array}$ \\
\hline
\end{tabular}

Source: Ding, G.K.C., Sustainable construction-The role of environmental assessment tools, Journal of Environmental Management, 86, 451-464, (2008).

\section{LEED Rating Systems}

LEED System was first published in 1999, it has been helping to improve the quality of buildings and their impact on the environment. LEED is a certification program that gives the tools to have a measurable impact on buildings' performance. LEED promotes a whole-building approach to sustainability by recognizing performance in five key areas of human and environmental health: sustainable site development, water savings, energy efficiency, materials selection and indoor environmental quality ${ }^{[9]}$. LEED rating system includes the following scoring modules ${ }^{[2]}$ :

\section{○ New Construction}

LEED for New Construction and Major Renovations is designed to guide and distinguish high-performance commercial and institutional projects.

○ Existing Buildings: Operations \& Maintenance

LEED for Existing Buildings: Operations \& Maintenance provides a benchmark for building owners and operators to measure operations, improvements and maintenance. 


\section{○ Commercial Interiors}

LEED for Commercial Interiors is a benchmark for the tenant improvement market that gives the power to make sustainable choices to tenants and designers.

○ Core \& Shell

LEED for Core \& Shell aids designers, builders, developers and new building owners in implementing sustainable design for new core and shell construction.

○ Schools

LEED for Schools recognizes the unique nature of the design and construction of K-12 schools and addresses the specific needs of school spaces.

\section{○ Retail}

LEED for Retail recognizes the unique nature of retail design and construction projects and addresses the specific needs of retail spaces.

○ Healthcare

LEED for Healthcare promotes sustainable planning, design and construction for high-performance healthcare facilities.

○ Homes

LEED for Homes promotes the construction of high-performance green homes.

\section{○ Neighborhood Development}

LEED for Neighborhood Development integrates the principles of smart growth, urbanism and green building into the national program for neighborhood design.

\section{Assessment Process}

LEED checklist has six categories: 1) site selection, 2) water efficiency, 3) energy and atmosphere, 4) indoor environment, 5) materials used, and 6) innovation and design process. The categories have some prerequisites must be achieved, and some credits. Based on the number of recorded points, the project can be rated to get the platinum, golden, silver, or certified rates. But as for the evaluation here, and because it is not a matter of ranking, the paper only benchmarks the 
points achieved as percentage of each categories as a guide for the overall performance of the building (Fig. 3) ${ }^{[9]}$.

Project Totals are 69 Possible Points. For LEED NC., V2.2, Certified 26-32 points Silver 33-38 points Gold 39-51 points Platinum 52-69 points ${ }^{[9]}$, while for LEED NC. 2009, there are some more points for can be awarded for (Regional Priority), up to 4 credits are identified as Regional Priority credits. Projects outside of the U.S. are not eligible for Regional Priority credits ${ }^{[10]}$.

\section{The Case Study}

The case study presented and evaluated is a commercial building, located in Dammam city, Eastern Province, KSA. The lot area is $59,113.13 \mathrm{~m}^{2}$, and the building area is $50,589.54 \mathrm{~m}^{2}$. The building consists of ground floor used as covered parking, entrances and few anchor stores and shops, the first floor is mainly for shopping and food courts, while the mezzanine is for administrative offices and services. The building accommodates 180 shops, restaurants, play area, services, and 1,395 covered and on streetcar parking (Fig. 4- 6).

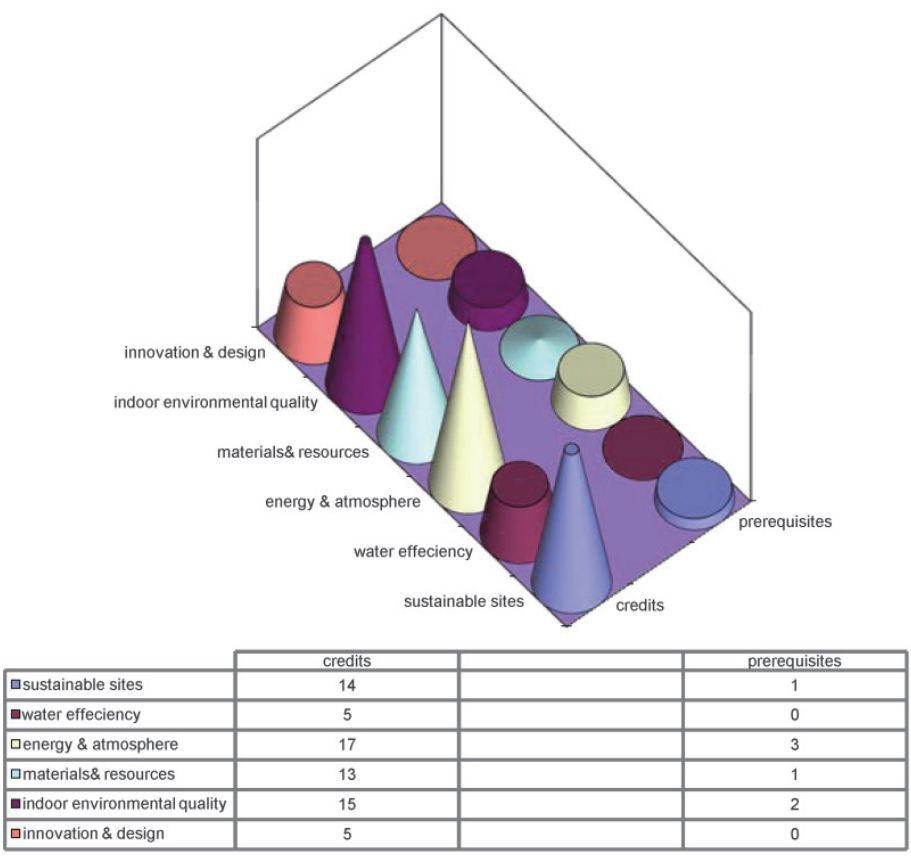

Fig. 3. LEED's Categories and their credits and prerequisites ${ }^{[9]}$. 


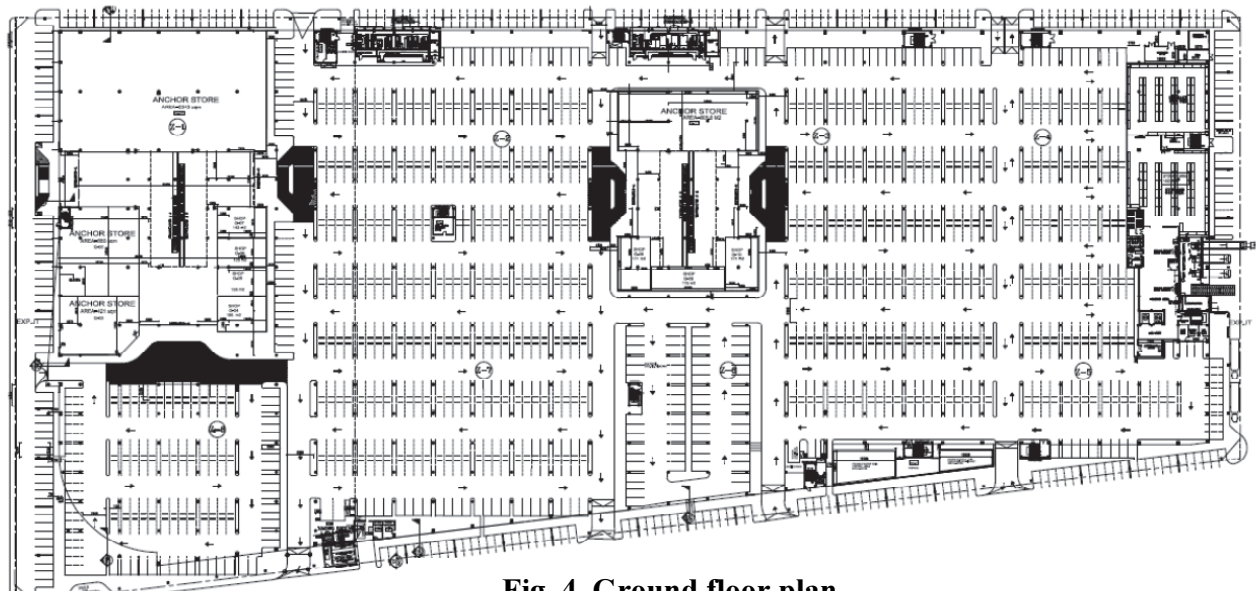

Fig. 4. Ground floor plan.

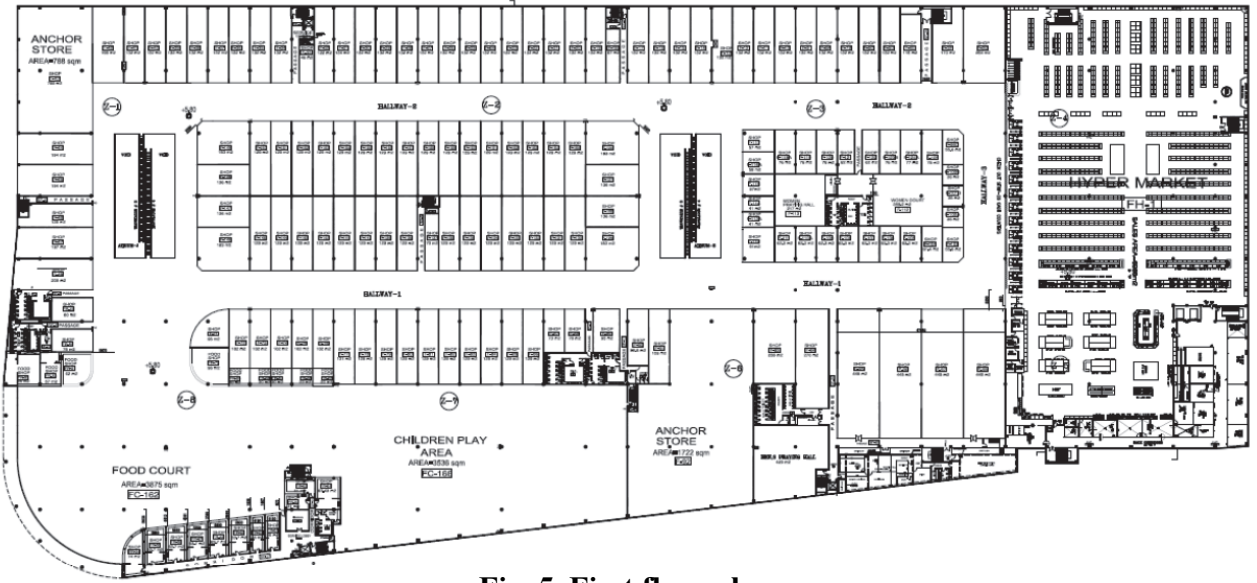

Fig. 5. First floor plan.

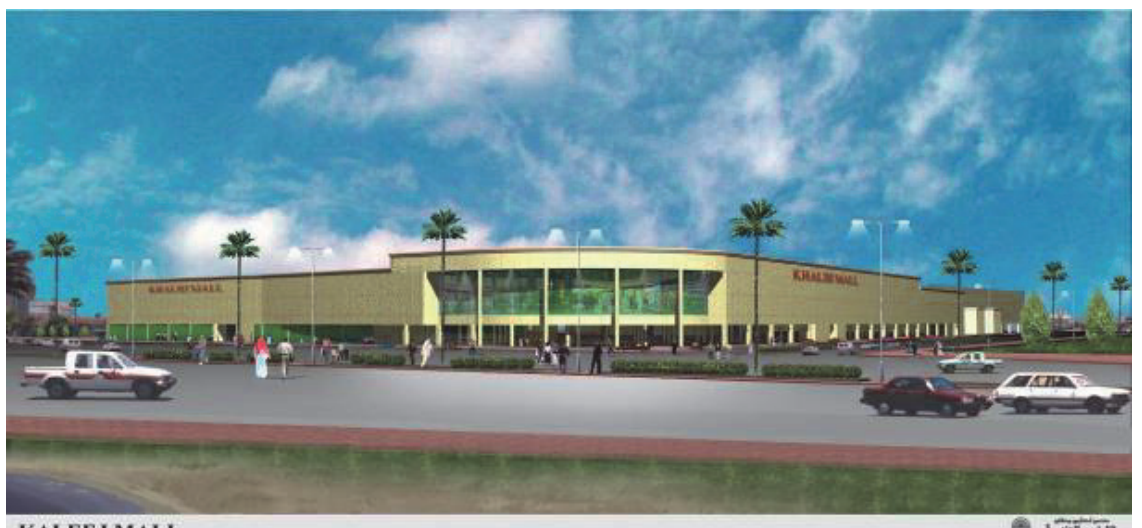

Fig. 6. The case study. 


\section{Analysis and Findings}

Table 5 summarizes the findings, technical changes suggested, and expected outcomes of changes. Applying the evaluation and scoring system of LEED, the following results are recorded:

\subsection{Sustainable Sites}

The building scores only few points for:

- Site selection: the building is not built on a farmland, or on land specified for threatened habitat lists, location is not within 50 feet of water bodies, and its land is not a parkland site.

○ Development density and community connectivity: the building is constructed within $1 / 2$ mile of a residential zone and within $1 / 2$ mile of basic services with pedestrian access between the building and the services. The location is along a high street connecting different districts of the city of Dammam. Basic services available there are: public park, mosques, grocery shops, bookshop, bakery, barbershop, laundry, meat shop, fresh vegetables and fruits shop, and schools.

- Alternative transportation, parking capacity: the parking capacity is designed to meet local zoning requirements, and there are parking areas can be used for carpools or vanpools with drop off and pick up areas.

O Heat island effect non-roof: as the project places more than $50 \%$ of parking spaces under the building. The ground floor is all designated for parking, with minimum area for the entrances of the mall.

- Heat island effect roof: as the finishing materials of the roof are of high-reflectance materials that reflect much of the sunlight. Materials used are very light color coating plaster applied on the plain concrete on the slabs. In addition, for the skylight, the corrugated sheets used have high reflectance value that does not affect the microclimate of the building.

○ Light pollution reduction: most of the building facades are opaque, without windows. Minimum external curtain walls are used for the entrances only. As a result most of the internal lighting fixtures don not leak light to outside of the building. 


\subsection{Water Efficiency}

The building scores only few points for:

○ Water efficient landscape, reduce by $50 \%$ : as there is no landscape around the building and as a result there is no use of potable water.

- Water efficient landscape, no potable use or no irrigation: As there is, no permanent irrigation required for the site.

○ Water use reduction by $20 \%$ : the lavatory faucets are of the photocell type, that open and close automatically by sensors of users. This helps reduce the burden on the municipal water supply and waste water systems.

\subsection{Energy \& Atmosphere}

The building scores only one point for:

o Fundamental commissioning of the building energy system: As the project, owner has designated an individual as the Commissioning Authority to lead, review and oversee the completion of the commissioning process activities.

\subsection{Materials \& Resources}

The building scores only few points for:

- Storage \& Collection of recyclables: there is an area that serves the entire building and is dedicated to the collection and storage of nonhazardous materials for recycling, including paper, corrugated cardboard, glass, plastics and metals.

○ Regional materials, $10 \& 20 \%$ extracted, processed\& manufactured: as there are many building materials, which are regionally produced in KSA and Emirates or less than 500 miles, based on the cost. The materials include bricks, cement, reinforcement, ceramic tiles and others.

\subsection{Indoor Environmental Quality}

The building scores only few points for:

○ Environmental Tobacco Smoke: smoking is prohibited in the building. 
○ Low emitting materials, composite wood \& agrifiber products: as the particleboard, medium density fiberboard (MDF), plywood composite wood products used on the interior of the building contain no added urea-formaldehyde resins. Laminating adhesives used to fabricate on-site and shop-applied composite wood and agrifiber assemblies contain no added urea-formaldehyde resins.

o Indoor chemical \& pollutant source control: there are permanent entryway systems in the primary direction of travel to capture dirt and particulates from entering the building. The system includes grilles and slotted systems that allow for cleaning underneath. In addition, parking lot occupies the ground floor in the open space so that it helps take cars exhaust out of building and allow fresh and clean air to replace it.

○ Controllability of systems, lighting: there are individual lighting controls for the shops and spaces in the building to enable adjustments to suit individual task needs and preferences.

- Controllability of systems, thermal comfort: there are individual thermal comfort control system for the shops, which have their own AC units separate from the AC system used for the corridors and food court areas. This enables adjustments to suit individual task needs.

While the building achieved some credits and prerequisites of LEED system, (displayed in Fig. 7, 8), the building lacks many other points. The overall credits achieved are 15 credits $(22 \%)$ out of 69 possible ones. In addition, the overall prerequisites achieved are $3(43 \%)$ out of required 7 prerequisites. The main problem of the building is related to the energy and atmosphere aspects. The building gains zero credit out or the 17 credits related to the energy and atmosphere. The maximum performance efficiency of the building is recorded in water use, which is relatively accepted as the building gains 3 credits $(60 \%)$ out of 5 available credits.

The building performance records $43 \%$ in sustainable sites selection aspects, $27 \%$ in indoor environmental quality aspects, and $15 \%$ in materials and resources aspects. As a result, the building is poor in its environmental performance related to sustainability issues established by LEED rating system. The building needs much more thorough studies and environmental management policies to enhance its sustainability criteria for better microclimate, health, and productivity for the occupants and users, and for a better environmental quality for the site location and surrounding context. 
Table 5. Summery Sheet of the Assessment of the Building and Technical Changes Suggested and Their Expected Impacts.

\begin{tabular}{|c|c|c|c|c|}
\hline $\begin{array}{l}\text { Assessment criteria } \\
\text { (USGBC 2009) }\end{array}$ & 总 & 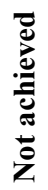 & Suggested technical changes & $\begin{array}{l}\text { Impacts of } \\
\text { changes }\end{array}$ \\
\hline \multicolumn{5}{|l|}{ Sustainable Sites } \\
\hline $\begin{array}{l}\text { Prereq } 1 \text { Construction } \\
\text { Activity Pollution } \\
\text { Prevention }\end{array}$ & & $x$ & NA & \\
\hline Credit 1 Site Selection & $\checkmark$ & & & \\
\hline $\begin{array}{l}\text { Credit } 2 \text { Development } \\
\text { Density \& Community } \\
\text { Connectivity }\end{array}$ & $\checkmark$ & & & \\
\hline $\begin{array}{l}\text { Credit } 3 \text { Brownfield } \\
\text { Redevelopment }\end{array}$ & & $x$ & NA & \\
\hline $\begin{array}{l}\text { Credit 4.1 Alternative } \\
\text { Transportation, Public } \\
\text { Transportation Access }\end{array}$ & & $x$ & $\begin{array}{l}\text { Arrange with the municipality to } \\
\text { provide a bus line and station }\end{array}$ & $\begin{array}{l}\text { reduce dependency } \\
\text { on private cars and } \\
\text { fuel consumption }\end{array}$ \\
\hline $\begin{array}{l}\text { Credit } 4.2 \text { Alternative } \\
\text { Transportation, Bicycle } \\
\text { Storage }\end{array}$ & & $x$ & $\begin{array}{l}\text { Provide cycle racks, storage and } \\
\text { shower rooms near to the building } \\
\text { entrance }\end{array}$ & $\begin{array}{l}\text { reduce dependency } \\
\text { on private cars and } \\
\text { fuel consumption }\end{array}$ \\
\hline $\begin{array}{l}\text { Credit } 4.3 \text { Alternative } \\
\text { Transportation Fuel } \\
\text { Efficient Vehicles }\end{array}$ & & $x$ & $\begin{array}{l}\text { Support the use of fuel-efficient } \\
\text { vehicles by providing parking areas } \\
\text { assigned for this type of vehicle in very } \\
\text { suitable locations. Install alternative } \\
\text { fuel fueling stations. }\end{array}$ & $\begin{array}{l}\text { reduce fuel } \\
\text { consumption by } \\
\text { transportation }\end{array}$ \\
\hline $\begin{array}{l}\text { Credit } 4.4 \text { Alternative } \\
\text { Transportation, Parking } \\
\text { Capacity }\end{array}$ & $\checkmark$ & & & \\
\hline $\begin{array}{l}\text { Credit 5.1 Site } \\
\text { Development, Protect or } \\
\text { Restore Habitat }\end{array}$ & & $x$ & $\begin{array}{l}\text { Provide plantation areas around the site } \\
\text { and indoor plants as well }\end{array}$ & $\begin{array}{l}\text { promote } \\
\text { biodiversity }\end{array}$ \\
\hline $\begin{array}{l}\text { Credit } 5.2 \text { Site } \\
\text { Development, Maximize } \\
\text { Open Space }\end{array}$ & & \begin{tabular}{|l|}
$x$ \\
\end{tabular} & $\begin{array}{l}\text { Provide open spaces in the lot next to } \\
\text { the site, and study the possibility of } \\
\text { providing a partially covered roof } \\
\text { garden in the building }\end{array}$ & $\begin{array}{l}\text { promote } \\
\text { biodiversity }\end{array}$ \\
\hline $\begin{array}{l}\text { Credit 6.1 Storm water } \\
\text { Design, Quantity Control }\end{array}$ & & $x$ & $\begin{array}{l}\text { Collect storm water and reuse for } \\
\text { landscape irrigation and toilet flushing. } \\
\text { use vegetated roofs, and pervious } \\
\text { paving materials }\end{array}$ & $\begin{array}{l}\text { save storm water } \\
\text { flows and promote } \\
\text { infiltration }\end{array}$ \\
\hline $\begin{array}{l}\text { Credit 6.2 Storm water } \\
\text { Design, Quality Control }\end{array}$ & & $x$ & $\begin{array}{l}\text { Use vegetated filters and open } \\
\text { channels to treat storm water runoff. }\end{array}$ & $\begin{array}{l}\text { reduce pollution of } \\
\text { runoff water }\end{array}$ \\
\hline $\begin{array}{l}\text { Credit 7.1 Heat Island } \\
\text { Effect, Non-Roof }\end{array}$ & $\checkmark$ & & & \\
\hline $\begin{array}{l}\text { Credit } 7.2 \text { Heat Island } \\
\text { Effect, Roof }\end{array}$ & $\checkmark$ & & & \\
\hline $\begin{array}{l}\text { Credit } 8 \text { Light Pollution } \\
\text { Reduction }\end{array}$ & $\checkmark$ & & & \\
\hline Water Efficiency & & & & \\
\hline $\begin{array}{l}\text { Credit } 1.1 \text { Water Efficient } \\
\text { Landscaping, Reduce by } 50 \%\end{array}$ & $\checkmark$ & & & \\
\hline $\begin{array}{l}\text { Credit } 1.2 \text { Water Efficient } \\
\text { Landscaping, No Potable, } \\
\text { No Irrigation }\end{array}$ & $\checkmark$ & & & \\
\hline
\end{tabular}


Table 5. Ccontd.

\begin{tabular}{|c|c|c|c|c|}
\hline Assessment criteria & 总 & 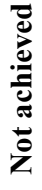 & Suggested technical changes & $\begin{array}{l}\text { Impacts of } \\
\text { changes }\end{array}$ \\
\hline \begin{tabular}{|l|} 
Credit 2 Innovative \\
Wastewater Technologies
\end{tabular} & & $x$ & $\begin{array}{l}\text { Use onsite wastewater treatment such } \\
\text { as biological nutrient removal systems, } \\
\text { and high efficiency filtration systems }\end{array}$ & $\begin{array}{l}\text { reduce wastewater } \\
\text { volume }\end{array}$ \\
\hline $\begin{array}{l}\text { Credit 3.1 Water Use } \\
\text { Reduction, } 20 \% \\
\text { Reduction }\end{array}$ & \begin{tabular}{|l|l} 
\\
\end{tabular} & & & \\
\hline $\begin{array}{l}\text { Credit } 3.2 \text { Water Use } \\
\text { Reduction, } 30 \% \\
\text { Reduction }\end{array}$ & & $x$ & $\begin{array}{l}\text { Increase the use of water saving } \\
\text { fixtures and fittings such as water } \\
\text { closets and kitchen sinks. }\end{array}$ & $\begin{array}{l}\text { reduce the burden } \\
\text { on the municipal } \\
\text { water and waste }\end{array}$ \\
\hline Energy \& Atmosphere & & & & \\
\hline $\begin{array}{l}\text { Prereq 1 Fundamental } \\
\text { Commissioning of the } \\
\text { Energy Systems }\end{array}$ & \begin{tabular}{|l|}
$\checkmark$ \\
\end{tabular} & & & \\
\hline $\begin{array}{l}\text { Prereq } 2 \text { Minimum } \\
\text { Energy Performance }\end{array}$ & & $x$ & $\begin{array}{l}\text { Use a computer simulation model to } \\
\text { assess the energy performance and the } \\
\text { most cost-effective measures. Comply } \\
\text { with ASHREA Energy Design Guide } \\
\text { of Retail Buildings } 2006\end{array}$ & $\begin{array}{l}\text { reduce } \\
\text { environmental and } \\
\text { economic impacts } \\
\text { resulting from use } \\
\text { of excessive } \\
\text { energy }\end{array}$ \\
\hline \begin{tabular}{|l|} 
Prereq 3 Fundamental \\
Refrigerant Management
\end{tabular} & & $x$ & $\begin{array}{l}\text { Identify HVAC equipments that use } \\
\text { CFC refrigerants and prepare } \\
\text { replacement schedule for them, then } \\
\text { specify new equipment that use no } \\
\text { CFC -based refrigerants }\end{array}$ & $\begin{array}{l}\text { reduce ozone } \\
\text { depletion }\end{array}$ \\
\hline $\begin{array}{l}\text { Credit } 1 \text { Optimize Energy } \\
\text { Performance }\end{array}$ & & $x$ & 20 & \\
\hline $\begin{array}{l}\text { Credit } 2 \text { On-Site } \\
\text { Renewable Energy }\end{array}$ & & $x$ & $\begin{array}{l}\text { Use any of photovoltaic cells, wind } \\
\text { power, biogas, or geothermal power } \\
\text { systems to provide part of the required } \\
\text { building energy }\end{array}$ & $\begin{array}{l}\text { reduce use of } \\
\text { fossil fuels and its } \\
\text { related } \\
\text { environmental } \\
\text { problems }\end{array}$ \\
\hline $\begin{array}{l}\text { Credit } 3 \text { Enhanced } \\
\text { Commissioning }\end{array}$ & & $x$ & NA & \\
\hline $\begin{array}{l}\text { Credit } 4 \text { Enhanced } \\
\text { Refrigerant Management }\end{array}$ & & $x$ & NA & \\
\hline $\begin{array}{l}\text { Credit } 5 \text { Measurement \& } \\
\text { Verification }\end{array}$ & & $x$ & $\begin{array}{l}\text { Create a baseline performance of a } \\
\text { similar energy efficient building by } \\
\text { computer simulation. Install metering } \\
\text { equipments to measure energy use, and } \\
\text { evaluate the energy system } \\
\text { performance of the building, compare } \\
\text { the actual consumption with the } \\
\text { baseline performance }\end{array}$ & $\begin{array}{l}\text { provide continuing } \\
\text { liability of energy } \\
\text { consumption of the } \\
\text { building }\end{array}$ \\
\hline Credit 6 Green Power & & $x$ & $\begin{array}{l}\text { Connect the building to a grid source } \\
\text { of renewable energy with adjacent } \\
\text { buildings }\end{array}$ & $\begin{array}{l}\text { reduce pollution } \\
\text { related to energy } \\
\text { to zero }\end{array}$ \\
\hline
\end{tabular}


Table 5. Contd.

\begin{tabular}{|c|c|c|c|c|}
\hline Assessment criteria & 总 & 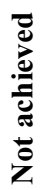 & Suggested technical changes & Impacts of changes \\
\hline \multicolumn{5}{|l|}{ Materials \& Resources } \\
\hline $\begin{array}{l}\text { Prereq 1 Storage \& } \\
\text { Collection of Recyclables }\end{array}$ & $\checkmark$ & & & \\
\hline $\begin{array}{l}\text { Credit } 1.1 \text { Building } \\
\text { Reuse, Maintain } 75 \% \text { of } \\
\text { Existing elements }\end{array}$ & & $x$ & NA & \\
\hline $\begin{array}{l}\text { Credit 1.2 Building } \\
\text { Reuse, Maintain } 95 \% \text { of } \\
\text { Existing elements }\end{array}$ & & $x$ & NA & \\
\hline $\begin{array}{l}\text { Credit 1.3 Building } \\
\text { Reuse, Maintain } 50 \% \text { of } \\
\text { Non-Structural Elements }\end{array}$ & & $x$ & NA & \\
\hline $\begin{array}{l}\text { Credit 2.1 Construction } \\
\text { Waste Management, } \\
\text { Divert } 50 \% \text { from } \\
\text { Disposal }\end{array}$ & & $x$ & NA & \\
\hline $\begin{array}{l}\text { Credit } 2.2 \text { Construction } \\
\text { Waste Management, } \\
\text { Divert } 75 \% \text { from } \\
\text { Disposal }\end{array}$ & & $x$ & NA & \\
\hline $\begin{array}{l}\text { Credit 3.1 Materials } \\
\text { Reuse, } 5 \%\end{array}$ & & $x$ & NA & \\
\hline $\begin{array}{l}\text { Credit 3.2 Materials } \\
\text { Reuse, } 10 \%\end{array}$ & & $x$ & NA & \\
\hline $\begin{array}{l}\text { Credit } 4.1 \text { Recycled } \\
\text { Content, } 10 \% \text { (post- } \\
\text { consumer }+1 / 2 \text { pre- } \\
\text { consumer) }\end{array}$ & & $x$ & NA & \\
\hline $\begin{array}{l}\text { Credit } 4.2 \text { Recycled } \\
\text { Content, } 20 \% \text { (post- } \\
\text { consumer }+1 / 2 \text { pre- } \\
\text { consumer) }\end{array}$ & & $x$ & NA & \\
\hline $\begin{array}{l}\text { Credit 5.1 Regional } \\
\text { Materials, } 10 \% \text { Extracted } \\
\text { \& Manufactured } \\
\text { regionally }\end{array}$ & $\checkmark$ & & & \\
\hline $\begin{array}{l}\text { Credit 5.2 Regional } \\
\text { Materials, } 20 \% \text { Extracted } \\
\text { \& Manufactured } \\
\text { regionally }\end{array}$ & & $x$ & NA & \\
\hline $\begin{array}{l}\text { Credit } 6 \text { Rapidly } \\
\text { Renewable Materials }\end{array}$ & & $x$ & $\overline{\mathrm{NA}}$ & \\
\hline Credit 7 Certified Wood & & $x$ & NA & \\
\hline $\begin{array}{l}\text { Indoor Environmental } \\
\text { Quality }\end{array}$ & & & & \\
\hline $\begin{array}{l}\text { Prereq } 1 \text { Minimum IAQ } \\
\text { Performance }\end{array}$ & & $x$ & $\begin{array}{l}\text { Change the ventilation system to } \\
\text { meet ASHREA standards }\end{array}$ & $\begin{array}{l}\text { ensure comfort and } \\
\text { wellness of the users }\end{array}$ \\
\hline $\begin{array}{l}\text { Prereq } 2 \text { Environmental } \\
\text { Tobacco Smoke (ETS) } \\
\text { Control }\end{array}$ & $\checkmark$ & & & \\
\hline
\end{tabular}


Table 5. Contd.

\begin{tabular}{|c|c|c|c|c|}
\hline Assessment criteria & 苞 & 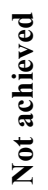 & Suggested technical changes & Impacts of changes \\
\hline $\begin{array}{l}\text { Credit } 1 \text { Outdoor Air } \\
\text { Delivery Monitoring }\end{array}$ & & $x$ & $\begin{array}{l}\text { Install airflow and } \mathrm{Co}^{2} \text { measuring } \\
\text { tools, and use alarm systems for } \\
\text { possible deficiency in outdoor air } \\
\text { delivery }\end{array}$ & $\begin{array}{l}\text { promote occupants } \\
\text { comfort and wellness }\end{array}$ \\
\hline $\begin{array}{l}\text { Credit } 2 \text { Increased } \\
\text { Ventilation }\end{array}$ & & $x$ & $\begin{array}{l}\text { Use heat recovery systems to } \\
\text { minimize the additional energy } \\
\text { consumption associated by higher } \\
\text { rates of ventilation }\end{array}$ & $\begin{array}{l}\text { promote users health } \\
\text { and productivity }\end{array}$ \\
\hline $\begin{array}{l}\text { Credit 3.1 Construction } \\
\text { IAQ Management Plan, } \\
\text { During Construction }\end{array}$ & & $x$ & NA & \\
\hline $\begin{array}{l}\text { Credit 3.2 Construction } \\
\text { IAQ Management Plan, } \\
\text { Before Occupancy }\end{array}$ & & $x$ & NA & \\
\hline $\begin{array}{l}\text { Credit 4.1 Low-Emitting } \\
\text { Materials, Adhesives \& } \\
\text { Sealants }\end{array}$ & & $x$ & $\begin{array}{l}\text { When refurbishing the buildings, } \\
\text { use materials that comply with the } \\
\text { Air Quality Management, or the } \\
\text { Green Seal Standard, whichever is } \\
\text { appropriate }\end{array}$ & $\begin{array}{l}\text { reduce indoor } \\
\text { contamination }\end{array}$ \\
\hline $\begin{array}{l}\text { Credit 4.2 Low-Emitting } \\
\text { Materials, Paints \& } \\
\text { Coatings }\end{array}$ & & 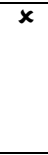 & $\begin{array}{l}\text { When refurbishing the buildings, } \\
\text { use materials that comply with the } \\
\text { Air Quality Management, or the } \\
\text { Green Seal Standard, whichever is } \\
\text { appropriate }\end{array}$ & $\begin{array}{l}\text { reduce indoor } \\
\text { contamination }\end{array}$ \\
\hline $\begin{array}{l}\text { Credit 4.3 Low-Emitting } \\
\text { Materials, Carpet } \\
\text { Systems }\end{array}$ & & $x$ & $\begin{array}{l}\text { When refurbishing the buildings, } \\
\text { use materials that comply with the } \\
\text { Air Quality Management, or the } \\
\text { Green Seal Standard, whichever is } \\
\text { appropriate }\end{array}$ & $\begin{array}{l}\text { reduce indoor } \\
\text { contamination }\end{array}$ \\
\hline $\begin{array}{l}\text { Credit 4.4 Low-Emitting } \\
\text { Materials, Composite } \\
\text { Wood Products }\end{array}$ & $\checkmark$ & & & \\
\hline $\begin{array}{l}\text { Credit 5 Indoor Chemical } \\
\& \text { Pollutant Source } \\
\text { Control }\end{array}$ & $\checkmark$ & & & \\
\hline $\begin{array}{l}\text { Credit } 6.1 \text { Controllability } \\
\text { of Systems, Lighting }\end{array}$ & $\checkmark$ & & & \\
\hline $\begin{array}{l}\text { Credit } 6.2 \text { Controllability } \\
\text { of Systems, Thermal } \\
\text { Comfort }\end{array}$ & $\checkmark$ & & & \\
\hline $\begin{array}{l}\text { Credit 7.1 Thermal } \\
\text { Comfort, Design }\end{array}$ & & $x$ & $\begin{array}{l}\text { Introduce passive heating and } \\
\text { cooling systems within the } \\
\text { buildings such as: Trombe wall, } \\
\text { sun space, thermal chimney ... }\end{array}$ & $\begin{array}{l}\text { reduce AC heating and } \\
\text { cooling loads }\end{array}$ \\
\hline $\begin{array}{l}\text { Credit } 7.2 \text { Thermal } \\
\text { Comfort, Verification }\end{array}$ & & $\mathbf{x}$ & $\begin{array}{l}\text { Provide monitoring systems for } \\
\text { the thermal environment and } \\
\text { prepare corrective measures. }\end{array}$ & $\begin{array}{l}\text { assess the thermal } \\
\text { comfort of occupants }\end{array}$ \\
\hline $\begin{array}{l}\text { Credit } 8.1 \text { Daylight \& } \\
\text { Views, Daylight } 75 \% \text { of } \\
\text { Spaces }\end{array}$ & & $x$ & NA & \\
\hline $\begin{array}{l}\text { Credit } 8.2 \text { Daylight } \& \\
\text { Views, Views for } 90 \% \text { of } \\
\text { Spaces }\end{array}$ & & $x$ & NA & \\
\hline
\end{tabular}




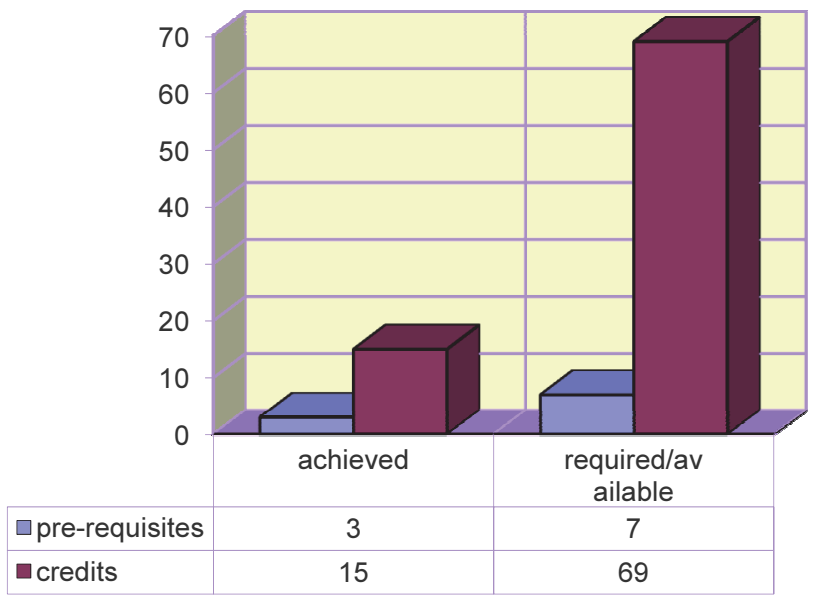

Fig. 7. The case study environmental performance based on LEED rating system.

\section{Sustainable Sites Selection}

achieved,

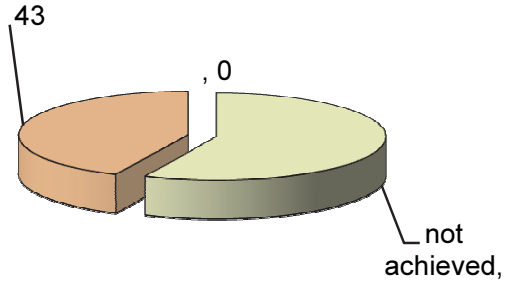

57

\section{Indoor Environment}

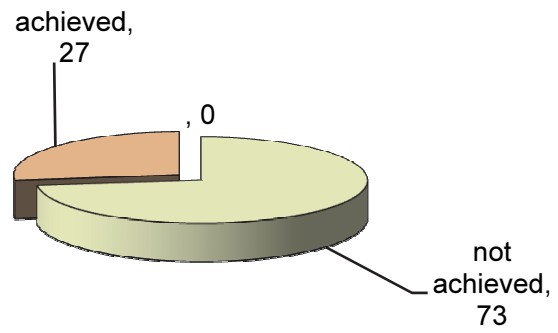

Water Use

achieved

60

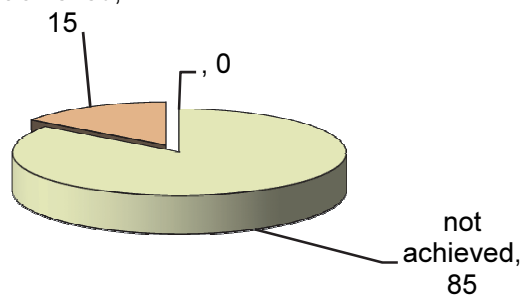

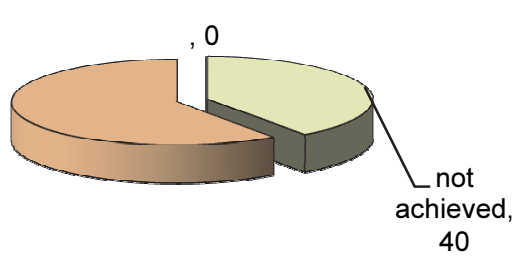


Energy \& Atmosphere

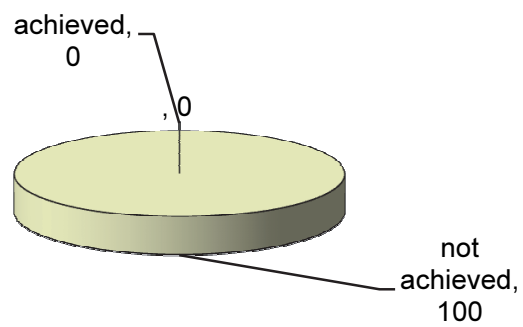

Overall Performance (credits \& prerequisites)

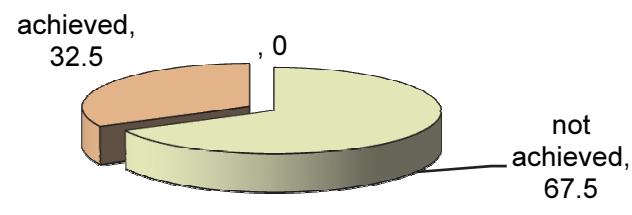

Fig. 8. The performance of the case study.

\section{Recommendations}

Based on the outcomes of this paper, two levels of recommendation are suggested;

- Case study related recommendations: More attention should be directed to the building performance especially in the aspects of: providing parking spaces and changing rooms for cyclists, light pollution reduction through the building envelop, waste water treatment technology, water use reduction, minimum energy performance, on-site renewable energy production and green power, minimum IAQ performance, outdoor air delivery monitoring, increased ventilation, control and verification of thermal comfort, and day lighting wherever appropriate.

○ General aspects recommendations: Sustainability issues should be a benchmark in all real estate development in KSA and the governmental should have a very strong role to ensure the achievement of such issues. Workshops, training courses, symposiums should be planned for building professionals in both private and public sectors to emphasize the importance and strategies of achieving sustainable built environment. Schools, architectural groups, engineers syndicate, should have leading efforts in increasing the public awareness of sustainable environmental development for the public.

\section{References}

[1] Ding, G.K.C., Sustainable construction-The role of environmental assessment tools, Journal of Environmental Management, 86, 451-464, (2008). 
[2] http:// www.usgbc.org/leed

[3] Harris, D.J., A quantitative approach to the assessment of the environmental impacts of building materials, Building and Environment Journal, 34, 751-758, (1999).

[4] Haapio, A. and Viitanniem, P. I., A critical review of building environmental assessment tools, Environmental Impact Assessment Review, 28, 469-482, (2008).

[5] Reijnders, L., and Roekel, A. van, Comprehensiveness and adequacy of tools for the environmental improvement of buildings, Journal of Cleaner Production, 7, 221-225, (1999).

[6] Lippiatt, B. C., Building for environmental and economic sustainability. Technical manual and user guide (BEES 4.0, National Institute of Standards and Technology (NIST), vol. 7423. Report NISTIR, (2007).

[7] Burnet, J., City buildings-Eco-labels and shades of green, Landscape and Urban Planning Journal, 83, 29-38, (2007).

[8] ASTM International, Standard Terminology for Sustainability Relative to the Performance of Building, E 2114-01(2001).

[9] USGBC, LEED for new construction and major renovations v2.2, U.S Green Building Council, (2005).

[10] USGBC, LEED for new construction and major renovations 2009, U.S Green Building Council, (2009). 


\section{استخدام نموذج LEED للتقييم البيئي لمعايير الاستدامة: دراسة حالة بمركز تجاري}

\section{محمد عبد الموجود عبد الغفار}

كلية العدارة والتخطبط، جامعة الدمام، المدلكة العربية السعودية

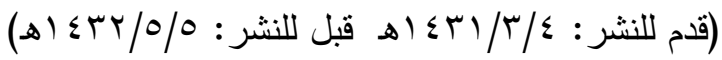

الهستخلص: ثبت عمليا التأثثر البيئي الضـار لصناعة البناء، الذي في

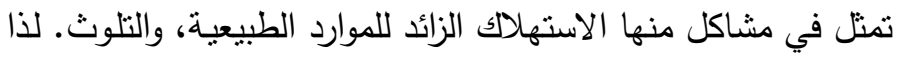

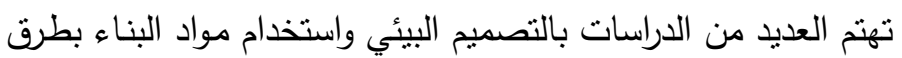

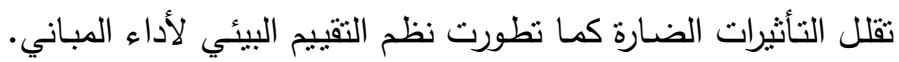

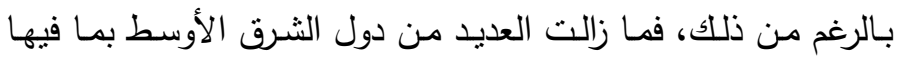

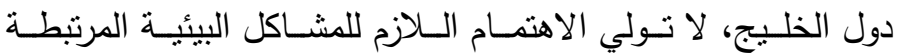
بصناعة البناء. قد يكون ذللك لنقص الوعي البيئي لدي المجتمع وعند

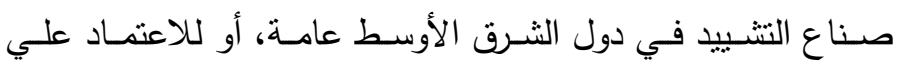

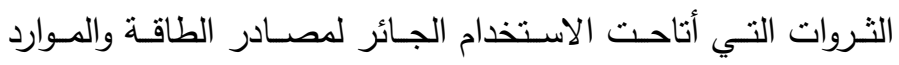
الطبيعية بدون اعتبارات لاحتباجات الغد.

تتمثل أهداف البحث في جذب انتباه المستخدمين إلي أهمية

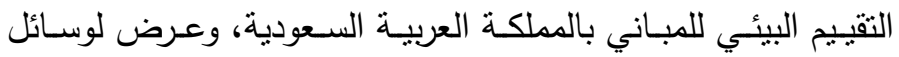
التقييم البيئي لتحقيق مبادئ الاستـامة، وتقديم نموذج تقيميم الأداء

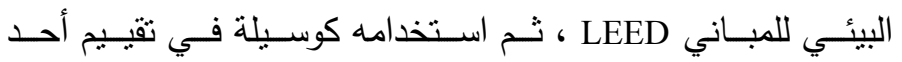
المجمعات التجارية بالدمام. وتم التقييم علي أساس المواصفات البيئية

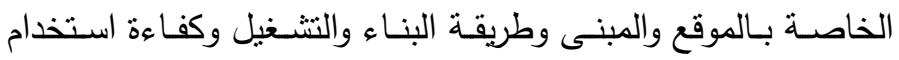

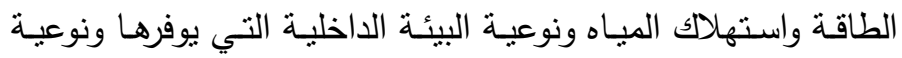
مواد البناء المستخدمة. ولهاء 
يقدم البحث شرحا مبسطا لنموذج التقييم أولاً، ثم يعرض حالة

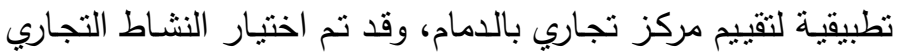

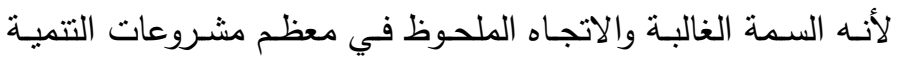
والنظوبر العقاري بدول الخليج عامة وهو من أهم عناصر الاستثمار

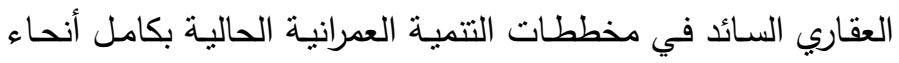

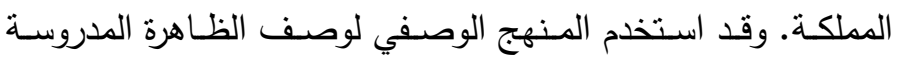
وتصــويرها كميـا، والمـنهج المقـارن لإجـراء مقارنــة بـين الظــاهرة

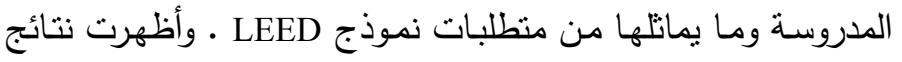

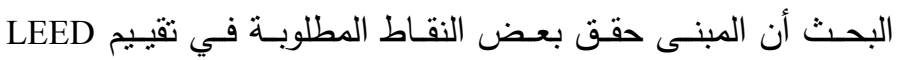

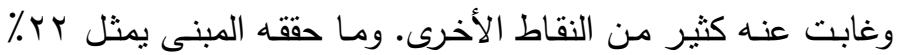

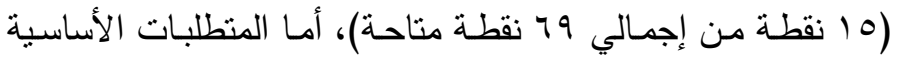

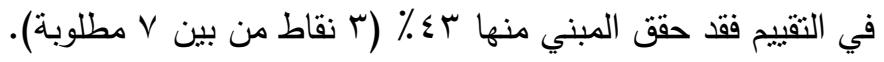
ترتبط المعضـلات الأساسية بـالمبنى بالطاقـة و المنـاخ، فلم

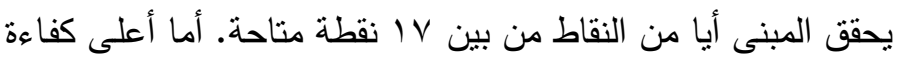

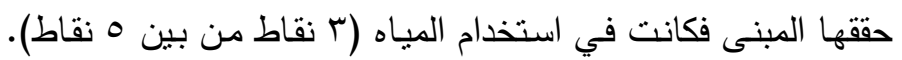

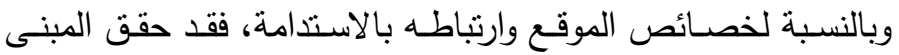

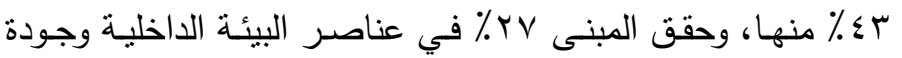

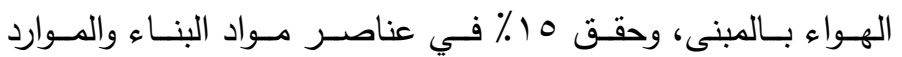
الطبيعية. لذلك يعتبر المبني فقيرا في أدائه البيئي.

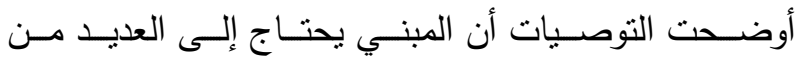

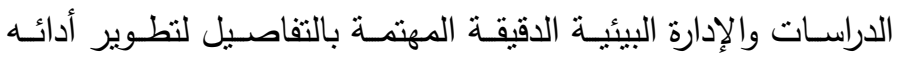

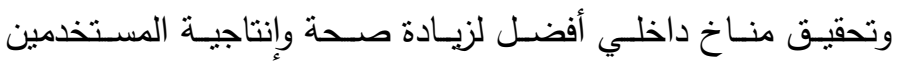
وتحقيق جودة بيئية أفضل للموقع وما يحيطه. الكلمات الدفتاحية: أداء المبـاني، التقبيم البيئي، الإنشـاء المستـام، التنمية المستدامة، نظام ليد. 